\title{
Correction to: Should Animalists Be "Transplanimalists"?
}

\section{Jeremy W. Skrzypek ${ }^{1} \cdot$ Dominic Mangino ${ }^{1}$}

Published online: 15 June 2020

(C) Springer Nature B.V. 2020

\section{Correction to: Axiomathes https://doi.org/10.1007/s10516-020-09482-y}

In the original publication, the second sentence of foot note 11 and final sentence of foot note 46 have been published incorrectly. The corrected foot notes are given in this correction.

The second sentence of foot note 11 should read as "(Thanks to Jason Eberl for bringing this suggestion to our attention.)".

The final sentence of foot note 46 should read as "(Thanks again to Jason Eberl for bringing this option to our attention)."

Publisher's Note Springer Nature remains neutral with regard to jurisdictional claims in published maps and institutional affiliations.

The original article can be found online at https://doi.org/10.1007/s10516-020-09482-y.

Jeremy W. Skrzypek

Jwskrzypek@umary.edu

Dominic Mangino

dominicmangino@gmail.com

1 University of Mary, 7500 University Dr., Bismarck, ND 58504, USA 